\title{
CAT MODEL FOR COMPLEX EVALUATION OF ORGANISATIONAL MATURITY IN SMALL AND MEDIUM ENTERPRISES
}

Hradílek, J.

Jaroslav Hradílek / Masaryk University, Brno, Faculty of Economics and Administration, Department of Corporate Economy, Lipová 507/41a, 60200 Brno, Czech Republic.Email: 10955@mail.muni.cz

\begin{abstract}
This paper deals with the need to complexly evaluate maturity, management, stakeholder relationship and resources utilisation of an organisation. It searches for an assessment tool independent on time and industry contexts. The research was conducted in two phases. The literature review on a set of existing performance models did not find any suitable tool. Based on that, a new performance model was created to assess the maturity of an organisation, focusing on soft factors like its leadership, processes and culture. It had been tested using structured interviews with managers in Czech, Slovak, German and Chinese companies. The model is based on a set of 17 non-financial criteria, divided into categories Management, Stakeholders and Resources. The results are given for each criterion, category and as an overall score. This article briefly describes the developed CAT model, methodology of its creation and validation and explains how it can be applied as an assessment tool. Its results can be benchmarked among different organisations/overtime to track development progress. Implications for Central European audience: This model gives both practitioners and researchers a lean, yet powerful tool to evaluate the maturity of an organisation with structured and measurable results. The new possibilities for quantitative research using the CAT model are now available for researchers to assess even larger samples of organisations with reasonable effort. For practitioners, the value is in a quick discovery of own weaknesses/strengths with structured results and recommendations. Model structure and selection of respondents ensures that the results are measurable and cover views of both management and employees.
\end{abstract}

Keywords: maturity; assessment; benchmarking; performance model JEL Codes: L26, L10, M14

\section{Introduction}

The maturity level of an organisation is an essential part of future success, regardless if it is a company or non-profit organisation. Most organisations strive to improve the efficiency of strategic changes implementation as they are weak at realising a change (Balogun \& Hope Hailey, 2004; Neely et al., 2002, and others). Neilson et al. (2009) cite a Booz \& Company survey on $1000+$ companies, where out of 125000 employees, $60 \%$ themselves admitted 
their companies are weak at change implementation. So how to help companies to adapt in order to survive?

Scholars generally accept the influence of organisational maturity on a performance (Belt et al., 2009; Dijkman et al., 2015, among many others). In our focus are also other soft factors like company culture, leadership, stakeholder relationship and resources utilisation. The extent and direct link of this influence are discussed (Kotter \& Heskett, 1992; Ogbonna \& Harris, 2000; Peters \& Waterman, 1982; Danso et al., 2019.) The complex set of factors having a direct or indirect influence on a company success will be in the paper called Maturity. We accept a definition of an organisational maturity by Nenadál (2016, p. 206): "The maturity of management system indicates such a state (level) of a managerial system in a certain organisation that enables long-term over-average and effective fulfilment of all stakeholders' requests". Having accepted that maturity and (directly or indirectly) other factors have an important influence on the long-term performance, are we capable of measuring them?

The goal of the study was to find a tool or performance model, which describes the soft factors in terms of qualitative, computable, but non-financial evaluation to give valid feedback to the organisation's management and owners. There are numerous performance models or financial analysis models already in place. Our focus was not laid on financial models. Although we acknowledge that financials are the ultimate result of company performance, management and processes, they still have certain drawbacks, analysing historical data instead of being predictive among the most serious ones. Among others (Hálek, 2016, p. 910) states that "In a global environment, where a major part of a business operates in an international environment, financial indicators seem insufficient, because for the most part they are historical indicators and do not reflect future developments". Therefore, the focus was on performance models and management techniques. The aim was to evaluate the maturity of an organisation. The result of evaluation must be delivered in numerical, comparable terms, focusing on questions like: Is there the purpose of the company expressed in terms like vision, mission, strategy? What is the alignment of the mid-level management and front-line employees to these? Does the company perform on its maximal utilisation level of its resources, or exists there a potential for better performance? These are just examples of important questions which - if not being actively managed by the organisations, can lead to the suboptimal performance and resources utilisation in the long run.

\section{Existing performance models}

Otley (1999) defines performance measurement as an information system that helps managers performing their job and managing the behaviour of the organisation. Maisel (2001) defines it as a system that enables an organisation to manage its performance and ensures that all the functions and activities are in line with the strategy to achieve the business results and create shareholder's value. Every such a performance model has been developed for a certain purpose and therefore has strong and weak sides. Also, the place and time of its creation have to be considered (Oger et al., 2002). Thought a unified definition is missing; the conclusion can be met that the performance management systems (PMS) have been developed primarily for the purpose of improving the management and performance of a company.

A well-designed measurement system must be accompanied by the process, people, systems and culture. The process can be defined as an existence of a process for reviewing, 
modifying and deploying measures, People - the availability of the required skills to use, reflect on, modify and deploy measures, Systems - the availability of flexible systems that enable the collection, analysis and reporting of appropriate data and culture is described as the existence of a measurement culture within the organisation ensuring that the value of measurement, and importance of maintaining relevant and appropriate measures, are appreciated (Kennerley \& Neely, 2003, p. 217). It also has to have strong cause-effect descriptive power, in best case in a form that describes the key processes/value flow in an enterprise and have good forecasting capabilities (Kaplan et al., 2000).

As most famous PMS, let's name Balanced Scorecard (Kaplan \& Norton, 2000), Performance prism (Neely et al., 2002), Performance pyramid - SMART (Lynch \& Cross, 1990). The practical usability in business can be questioned. Based on empirical researches (Frost, 2003; Suchánek, 2013; Afonina, 2015 and others), the most commonly used tools are SWOT analysis, Porter's five forces, PEST analysis and Balanced scorecard.

As practical usage does not provide us with any tool being able to give a non-financial assessment of an organisation, the theoretical research was conducted. After a literature review, there is a wide variety of performance models, tools and techniques. All of the selected and analysed tools are shown in Appendix 2.

This article thus introduces a new model serving mentioned purposes for evaluating and comparison of the maturity of an organisation. It will serve the management/owners of a company to better understand their company and to identify strong/weak sides. It enables them to compare the results over a certain time period or benchmark with other organisations.

\section{Methodology and data}

There were several phases of the research. The first phase consists of a review of existing models. In a second phase, an analysis of 37 existing PMS was conducted, deriving critical success factors, merging them into functional groups. As a next phase, a model has been created using the functional groups as categories and also using the business, management and controlling experience of the author. A testing and refining phase can be considered as a parallel because, after each interview, the feedback has been considered and reflected. However, the major change of the model emerged after seven evaluations, and that version forms the current model with minor improvements only. Having adopted all the valuable feedback from the business community, last two interviews have been conducted with three participants, with a results presentation not only on top management level but to middle management in one case and to all company staff in another.

In the first phase, the research was conducted on a literature review to identify PMS suitable for the purpose of evaluating and benchmarking the level of culture, leadership and maturity of an organisation. For the literature review, Wiley Online, Emerald and EBSCO Academic Search databases were reviewed, and Google Scholar was also used to look for relevant sources. In addition, books from the business and management fields were reviewed. Compilations and models overviews have also been used to increase the coverage. Still, there are several limitations to the literature review. Regardless of the effort and extent of a literature search, potentially valuable studies might have been missed. There is also the problem that only published studies have been taken into account, which creates a potential bias as unpublished studies might contain different outcomes. Another potential bias is the 
presence of subjectivity in the study retrieval process, which can occur in the choice of literature sources to include (de Waal, 2010).

The attempt to mitigate these biases was to include not primary sources only, but to include reviews and Recherches too. This should increase the span of the review and reduce the subjectivity bias. To find an acceptable PMS, there were three criteria based on Main Dimensions of PMS Models (Garengo et al., 2005) used and the desired model shall comply with all of them. They were:

1. Is the model dealing with culture, maturity \& leadership? [Strategy Alignment; Strategy Development; Focus on Stakeholders]

2. Are the results clear and comparable? [Depth; Breadth; Causal Relationships; Process Orientation]

3. Is the usage of the model easy even for SME? [Clarity and Simplicity; Balance]

note: In brackets are corresponding Garengo's dimensions. The Dynamic adaptability dimension was omitted as this is a trait for performance management systems and not applicable to (short term) evaluation tools).

Altogether, 76 models, tools and techniques were divided according to their purpose to groups Financials; Management tools; Performance management systems (PMS); Marketing and strategy tools; Tools and techniques - others. Out of them, only PMS were evaluated based on above-stated criteria, as the others were not PMS and therefore would not meet the purpose. The rankings were simple - comply $(1)$, partly $(0,5)$ or not compliant $(0)$. Out of analysed PMS, none has reached the required score, as is shown in Table 1. The complete list of models analysed and literature sources are listed in Appendix 2. It has to be noted that the ranking shows the appropriateness of a PMS to our purpose only, not an overall quality or usability of a model. 
Table 1 | Comparison of PMS based on Garengo's set of dimensions.

\begin{tabular}{|c|c|c|c|c|}
\hline Performance management system (PMS) & Crit. 1 & Crit. 2 & Crit. 3 & Total \\
\hline Baldrige performance excellence model & 1 & 1 & 0 & 2 \\
\hline BSC (Balanced Scorecard) & 0.5 & 0 & 1 & 1.5 \\
\hline Capability Maturity Model & 0.5 & 1 & 0.5 & 2 \\
\hline Dixon's performance questionnaire & 0.5 & 1 & 0 & 1.5 \\
\hline Dynamic Performance Management (DPM) & 0.5 & 1 & 0.5 & 2 \\
\hline EFQM & 1 & 1 & 0 & 2 \\
\hline ENAPS & 0.5 & 1 & 0 & 1.5 \\
\hline Keegan's performance measurement matrix & 0.5 & 0.5 & 0.5 & 1.5 \\
\hline Medori and Steeple Framework & 0.5 & 0 & 0.5 & 1 \\
\hline Performance Prism & 0.5 & 0 & 0.5 & 1 \\
\hline TOPP System & 0.5 & 1 & 0 & 1.5 \\
\hline $\begin{array}{l}\text { A performance measurement system for SMEs taking } \\
\text { part in Quality Award Programmes }\end{array}$ & 0.5 & 1 & 0.5 & 2 \\
\hline High Performance organisations framework & 1 & 0.5 & 0 & 1.5 \\
\hline ISAT & 0 & 1 & 0.5 & 1.5 \\
\hline Performance measurement system model & 0.5 & 0 & 0 & 0.5 \\
\hline The Enterprise Maturity Matrix & 0.5 & 1 & 0.5 & 2 \\
\hline Bititci's Reference model & 1 & 0.5 & 0 & 1.5 \\
\hline Performance Pyramid (SMART) & 1 & 0 & 0 & 1 \\
\hline The Results and Determinants Framework & 0.5 & 1 & 0.5 & 2 \\
\hline
\end{tabular}

Source: own elaboration

None of the PMS analysed scored well if we want them to compare the results among entities/overtime as they lack the measurable and comparable output while focusing on "soft" criteria. The only performance models fulfilling the need for clear and comparable results while dealing fully with Culture, Maturity and Leadership are EFQM and Baldrige award criteria, which are both very similar. Using Radar logic (EFQM) gives a score on a scale 01000 , which enables the researches and management/owners of the company to evaluate and even to benchmark. Both tools have quite a broad usage, and therefore the base for comparison is large enough. Moreover, the EFQM model is suitable also for non-profit organisations. Yet there is a serious obstacle for broader usage of them - the usage of these tools and assessment is complicated and especially small and medium organisations do not have enough resources for it (Aschenbrennerova, 2010). Its deployment requires to undertake a multiday training and hiring an external assessor. The assessment itself takes several days, which represents an effort that SMEs are usually not willing to invest. Moreover, as identified by (Rusev \& Salonitis, 2016, p. 277) “...the existing assessment tools are generally either biased towards process improvement or towards results. Assessment tools developed by Institutes that award prizes such as the MBQA and EFQM are results driven with little focus on culture and process efficiency". 


\subsection{Creation of the model}

Failed to find an appropriate model, next phase was to analyse the broad set of performance models and techniques which deal with strategy management or change management to derive a set of critical success factors (CSF). Only models that fulfilled the criteria being generally accepted (either published in an academic journal, or in own publication) have been included. Also, they have to be structured, and in a way, key factors can be drawn from the structure of the model. Certain models, therefore, cannot be included, though they are very popular (blue ocean strategy, benchmarking, customer satisfaction analysis etc.). Thirtyseven models have been therefore selected and analysed (see Table 1).

Table 1 | Performance models, tools and techniques overview

\begin{tabular}{|c|c|c|c|}
\hline Name of the model & Author(s) & Name of the model & Author(s) \\
\hline 5Forces model & Michael Porter & Good to Great & Jim Collins \\
\hline BCG & McKinsey & $\begin{array}{l}\text { Performance Pyramid } \\
\text { (SMART) }\end{array}$ & $\begin{array}{l}\text { Cross \& } \\
\text { Lynch }\end{array}$ \\
\hline $\begin{array}{l}\text { BSC (Balanced } \\
\text { Scorecard) }\end{array}$ & Kaplan, Norton & Performance Prism & A. D. Neely \\
\hline EFE matrix & Fred R. David & $\begin{array}{l}\text { Stankosky's Four Pillar } \\
\text { Knowledge Management } \\
\text { Model }\end{array}$ & $\begin{array}{l}\text { M. A. } \\
\text { Stankosky }\end{array}$ \\
\hline IFE matrix & Fred R. David & Harry Pollak's viability model & Harry Pollak \\
\hline PESTLE & Francis J. Aguilar & Argenti A-score & John Argenti \\
\hline SPACE & Radder \& Louw & Capability Maturity Model & $\begin{array}{l}\text { Watts } \\
\text { Humphrey }\end{array}$ \\
\hline SWOT & Albert Humphrey & $\begin{array}{l}\text { Six Sigma Business } \\
\text { Scorecard }\end{array}$ & Bill Smith \\
\hline VRIO & Jay B. Barney & $\begin{array}{l}\text { Keegan's performance } \\
\text { measurement matrix }\end{array}$ & $\begin{array}{l}\text { Daniel } \\
\text { Keegan }\end{array}$ \\
\hline Leavitt's diamond & Harold J. Leavitt & Sink and Tuttle model & Sink\&Tuttle \\
\hline McKinsey 7S & McKinsey & $\begin{array}{l}\text { Dixon's performance } \\
\text { questionnaire }\end{array}$ & Dixon et al. \\
\hline MIT 90's & $\begin{array}{l}\text { MIT team lead by M. S. } \\
\text { Morton }\end{array}$ & TOPP System & SINTEF \\
\hline EFQM & EFQM Foundation & Brown's model & Brown et al. \\
\hline $\begin{array}{l}\text { Baldrige performance } \\
\text { excellence model }\end{array}$ & M. Balridge & $\begin{array}{l}\text { Six dimensions performance } \\
\text { measures }\end{array}$ & $\begin{array}{l}\text { Fitzgerald et } \\
\text { al. }\end{array}$ \\
\hline $\begin{array}{l}\text { Lewin's three stage } \\
\text { model of change }\end{array}$ & Kurt Lewin & AMBITE & P. Bradley \\
\hline Four phases of change & Thomas B. Lawrence & ENAPS & ENAPS \\
\hline $\begin{array}{l}\text { Kotter's Eight Step } \\
\text { Change Model }\end{array}$ & John P. Kotter & $\begin{array}{l}\text { Medori and Steeple } \\
\text { Framework }\end{array}$ & $\begin{array}{l}\text { Medori \& } \\
\text { Steeple }\end{array}$ \\
\hline CorSet framework & $\begin{array}{l}\text { CorSet Framework } \\
\text { Institute }\end{array}$ & $\begin{array}{l}\text { Dynamic Performance } \\
\text { Management (DPM) }\end{array}$ & Maltz et al. \\
\hline Model CAF & $\begin{array}{l}\text { European Institute of } \\
\text { Public Administration }\end{array}$ & & \\
\hline
\end{tabular}

Source: (Bititci, 2015; Bencsik, 2017; Štamfestová 2013; Afonina, 2015), own elaboration. 
Out of the selected models, a list of 215 critical success factors has been identified. It provides a basis for the creation of criteria which CAT model uses. All the CSF derived are listed in Table 2.

Table 2 | Overview of key success factors derived from PMS's and their appearance

\begin{tabular}{|c|c|c|c|c|c|}
\hline CSF & $\begin{array}{l}\text { Occurr } \\
\text { ence }\end{array}$ & CSF & $\begin{array}{l}\text { Occurr } \\
\text { ence }\end{array}$ & CSF & $\begin{array}{l}\text { Occurr } \\
\text { ence }\end{array}$ \\
\hline processes & 12 & effectiveness & 1 & style & 1 \\
\hline employees & 10 & $\begin{array}{l}\text { stakeholder's } \\
\text { satisfaction }\end{array}$ & 1 & social responsibility & 1 \\
\hline finance & 9 & openness & 1 & customer loyalty & 1 \\
\hline quality & 9 & society & 1 & portfolio & 1 \\
\hline Innovativeness & 9 & entry barriers & 1 & logistics & 1 \\
\hline customers & 8 & process stimulation & 1 & change of systems & 1 \\
\hline market & 6 & management support & 1 & locality & 1 \\
\hline technology & 6 & infrastructure & 1 & implementation & 1 \\
\hline leadership & 6 & future growth & 1 & investors & 1 \\
\hline management & 5 & external environment & 1 & marketing & 1 \\
\hline flexibility & 5 & systematic work & 1 & equipment & 1 \\
\hline suppliers & 5 & sales and distribution & 1 & $\begin{array}{l}\text { firm's performance } \\
\text { measurement, analyse } \\
\text { and improvement }\end{array}$ & 1 \\
\hline R\&D & 5 & objectives & 1 & $\mathrm{KPI}$ & 1 \\
\hline costs & 4 & patience & 1 & management methods & 1 \\
\hline customer satisfaction & 4 & over debt & 1 & services & 1 \\
\hline strategy & 4 & market share & 1 & metrics & 1 \\
\hline environment & 3 & efficiency & 1 & resource value & 1 \\
\hline time & 3 & persuasion & 1 & defects rate & 1 \\
\hline structure & 3 & truth acceptance & 1 & rate of improvement & 1 \\
\hline culture & 3 & processes performance & 1 & systems & 1 \\
\hline profitability & 3 & $\begin{array}{l}\text { reaction on outside } \\
\text { impulses }\end{array}$ & 1 & cost position & 1 \\
\hline vision & 3 & capital structure & 1 & results durability & 1 \\
\hline education & 3 & regulation & 1 & reason for change & 1 \\
\hline IT & 2 & market research & 1 & design & 1 \\
\hline competition & 2 & fixation of desired state & 1 & turnover & 1 \\
\hline purchase management & 3 & competitiveness & 1 & waste & 1 \\
\hline government & 2 & controlling & 1 & Cash Flow & 1 \\
\hline organisation & 2 & supply chain & 1 & resource scarcity & 1 \\
\hline communication & 2 & resources utilisation & 1 & delivery reliability & 1 \\
\hline
\end{tabular}




\begin{tabular}{llllll} 
productivity & 2 & culture of discipline & 1 & operative effectiveness & 1 \\
resistance overcoming & 2 & change management & 1 & shared values & 1 \\
growth & 2 & $\begin{array}{l}\text { knowledge } \\
\text { management }\end{array}$ & 1 & supplies & 1 \\
planning & 2 & diversification & 1 & abilities & 1 \\
\hline
\end{tabular}

Source: own elaboration

Many of the factors were similar, which lead to the necessity to merge them together by relevance. The grouping method was similar to those of de Waal (2010): Because every author used a different terminology in his study, the elements were grouped into categories within each factor. Subsequently, a matrix per factor was constructed in which each category constitutes a characteristic. The only difference is that de Waal used $6 \%$ weighting of a characteristic to call it characteristic of High-Performance Organisation and that he verified the process with external academic, what was omitted in our case.

The process has had several iterations, grouping factors that were the same in content in a first step (e.g. KPI \& metrics). After that, the merging into functional groups followed, using besides de Waal HPO characteristics (Organisational design, Strategy, Processes, Technology, Leadership, Individuals \& Roles, Culture) also EFQM model characteristics (Leadership, People, Policy \& Strategy, Partnership \& Resources, Processes, Customers, Society, Performance). This was refined according to the real distribution of factors. So, groups like Exclusivity \& Quality were identified not being mentioned be either HPO or EFQM); Individuals \& Roles (HPO) was transferred to People (EFQM) and Employee selection (new criterion).

This process finished when all categories contained at least eight factors $(3 \%$ relevance ratio) and no unassigned factors remained. 13 groups outstand, which were so distinct that further merging would mean loss of information. The groups are Technology, Finance, Leadership, Effectivity, Suppliers, External environment, Exclusivity, Market, Quality, Employees, Culture, Processes and Controlling. Their distribution is shown on Figure 1.

Figure 1 | Success factors groups distribution from analysed PMS.

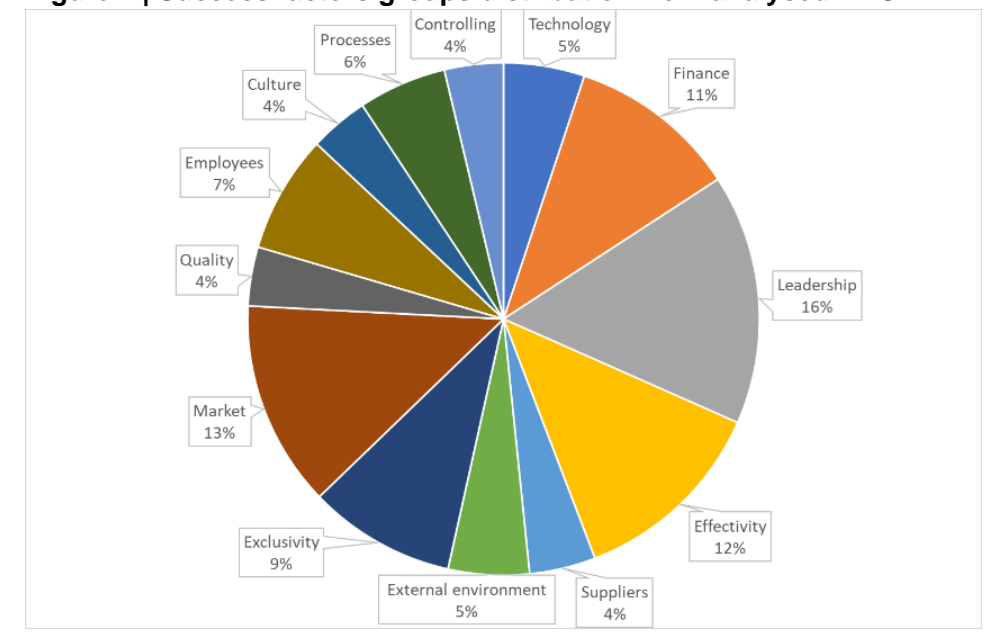

Source: own calculation 
Using the thirteen groups, the first version of the model was created. It has been developed based on principles of Globerson's (1985) performance criteria system, Garengo's et al. (2015) eight dimensions of performance measurement systems and principles of advanced quality systems (Nenadál, 2016).

The scaling of the model is in a range from 1 to 5 with 0.5 steps. The very simple and intuitive scaling also followed a logic used by most common process maturity models as they use the same principle (with the exception of 6 grades in case of ANSI/ASIS model). The 0.5 steps were added based on experience from field research when refinement was often needed. The overview of process maturity models is in Table 3.

Table 3 | Scaling overview of selected maturity models

\begin{tabular}{|c|c|c|c|c|c|}
\hline $\begin{array}{l}\text { Model - } \\
\text { description } \\
\text { / } \\
\text { Maturity } \\
\text { level }\end{array}$ & $\begin{array}{l}\text { QMMG } \\
- \\
\text { Quality } \\
\text { management } \\
\text { Maturity Grid }\end{array}$ & $\begin{array}{l}\text { CMM } \\
- \\
\text { Capability } \\
\text { Maturity Model }\end{array}$ & $\begin{array}{l}\text { COBIT } \\
- \\
\text { Control } \\
\text { Objectives for } \\
\text { Information and } \\
\text { related } \\
\text { Technology }\end{array}$ & $\begin{array}{l}\text { PMPM2 } \\
\text { - } \\
\text { Project } \\
\text { Management } \\
\text { Process Maturity } \\
\text { Model }\end{array}$ & $\begin{array}{l}\text { ANSI/ } \\
\text { ASIS } \\
- \\
\text { American } \\
\text { national Norm }\end{array}$ \\
\hline 1 & Uncertainty & Initial & Initial/Ad hoc & Ad-hoc & Pre-awareness \\
\hline 2 & Awakening & Managed & $\begin{array}{l}\text { Repeatable, but } \\
\text { intuitive }\end{array}$ & Planned & Project approach \\
\hline 3 & Enlightenment & Defined & Defined process & $\begin{array}{l}\text { Managed at } \\
\text { project level }\end{array}$ & $\begin{array}{l}\text { Program } \\
\text { approach }\end{array}$ \\
\hline 4 & Wisdom & $\begin{array}{l}\text { Quantitatively } \\
\text { Managed }\end{array}$ & $\begin{array}{l}\text { Managed and } \\
\text { measurable }\end{array}$ & $\begin{array}{l}\text { Managed at } \\
\text { corporate level }\end{array}$ & $\begin{array}{l}\text { Systems } \\
\text { approach }\end{array}$ \\
\hline 5 & Certainty & Optimising & Optimised & $\begin{array}{l}\text { Continuous } \\
\text { learning }\end{array}$ & $\begin{array}{l}\text { Management } \\
\text { system }\end{array}$ \\
\hline 6 & & & & & $\begin{array}{l}\text { Holistic } \\
\text { Management }\end{array}$ \\
\hline
\end{tabular}

Source: (Jokela et al., 2006; CMMI, 2010; Ariyadi \& Dirgahayu, 2015; Kwak \& Ibbs, 2002; ASIS, 2013, Nenadál, 2016).

\subsection{CAT Evaluation process}

Assessment procedure of target organisations is based on a structured interview with three key persons from an organisation (see chapter 6 for reasoning and selection). The main advantages are a direct information flow; ability to manage and control the assessment; correct potentially misunderstood questions; influence the selection of interviewees and instant feedback for the organisation. When the assessor has at least partial knowledge of the organisation, he can also evaluate the openness and fairness of the answers and therefore, the validity of the assessment.

The structured interview approach was also chosen as there are certain disadvantages of information gathering based on questionnaires, what would be a second, less demanding option. Firstly, the researcher has no control over the response rate and who has, in reality, responded (more often than not happens that top managers delegate the task of returning the questionnaire to a secretary or other staff member, diluting thus the results); secondly, as good the questions and answers might be, there is always a room for own interpretation; thirdly, some interviewers want to show their organisation better than it really is, tending to answer more favourably. Similarly, (Malina et al., 2011, p. 19) states: "We would also like to emphasise the importance of the method of questioning and reflective reasoning in creating 
important new insight. The Socratic method of questioning and logical reasoning is the backbone of academia and research".

To ensure comparability of results, the desired state for level 1, 3 and 5 are clearly described. For each criterion, there is a leading question. The respondent describes the state of the art of his organisation. The interviewer compares the answer with the prescripted evaluation for $1 / 3 / 5$ and suggests a result, reading the respective description. If the agreement is not met, they try to adjust the score comparing the actual situation with prescripted rankings. If no agreement can be met, the interviewer makes a final decision.

It is advisable that the evaluation is done by an assessor experienced with the CAT model, but not necessary. The testing can be done by own means, preferably a person from controlling or strategy department, having some knowledge about performance models and assessments (e.g. ISO, internal risk reviews...).

\subsection{Testing of the model}

Based on the above, it was decided to carry on the testing in the same way a real assessment would be, it means by accomplishing a series of structured interviews with managers of companies.

The objective of the testing was to evaluate and improve the model and get feedback from the business community. The model was adjusted and upgraded several times, so the results are not comparable at this time. The process involved several stages of iterations, improvement and reformulating (Malina et al., 2011, p. 17): "It is likely that the "finished" product that readers see is the result of much iteration of searching and interpreting the data, writing the results, and sparring with reviewers and editors". The testing phase was conducted similarly as if it is the real evaluation. The final version of the model is described in chapter 4.

\section{CAT (Complex Assessment Tool) model}

A new model is formed by three categories - Management, Stakeholders \& Resources with a total of 17 criteria covering the identified functional groups from Chapter 3.1. They are: for Management - Leadership, Corporate culture, Quality, Performance, Controlling, Processes, for Stakeholders - Communication, People, Employee selection process, Customers, Suppliers, Owners, Public authorities and for Resources - Financials, Exclusivity, Technology, External factors. All of 13 categories of CSF have been turned into criteria in the CAT model. During the testing period, based on the business community feedback, there were 3 criteria added to the model. All of them were added to the Stakeholders category: Communication, Owners (investors) and Public Authorities. The criterion Communication covers both internal and external communication within the organisation and namely, internal communication management/employees were often seen differently from the line employees and from the top. Internal communication is understood here as the strategic management of interactions and relationships between stakeholders at all levels within organisations (Welch \& Jackson, 2007). And original also Freeman's stakeholder model supports the addition of Owners and Public authorities (Freeman, 1984) criteria. Thereby 17 criteria divided into 3 categories form the CAT model. 
Each functional category has its subtotal to better identify strong/weak sides of an organisation Total achievable score is $17-85$, where upper quartile score - above 68 points indicates well managed, mature organisation, lower quartile (under 34) on the other hand, poorly managed entity likely to fail in a near future. The results are visualised for every respondent (and an average result) on a web chart indicating strengths and weaknesses.

The CAT model consists of the assessment methodology, the model itself, graphical output and structured interpretation of results.

The model includes "soft" factors of management like culture, leadership, vision and strategy. It stresses the utmost importance of these factors for an organisation's future. However, without transferring the visions into daily business by addressing factors like processes, stakeholders' relations and resources utilisation, no long-term success can be expected.

\subsection{Assessment methodology}

It includes the instructions on how to conduct an assessment, described in detail in chapter 3.2.

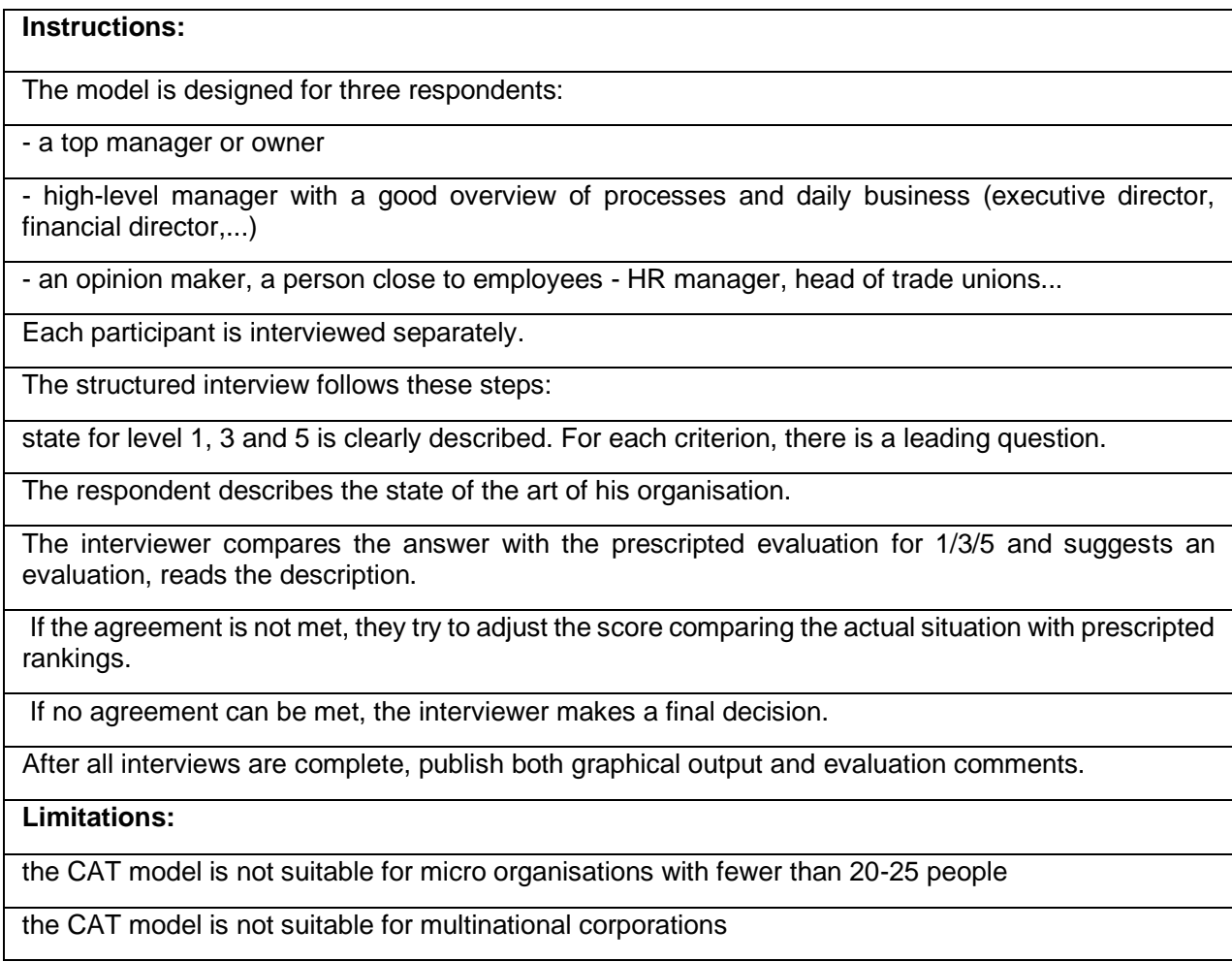

Source: own elaboration

It can be estimated that 1 hour is required for one interview. After completion of all responses, the graphical output is generated automatically. The interpretation is rather intuitive, looking for highest/lowest scores and for high spreads, which may indicate discontent in the organisation. 


\subsection{CAT model}

\section{Table 4 | CAT Model}

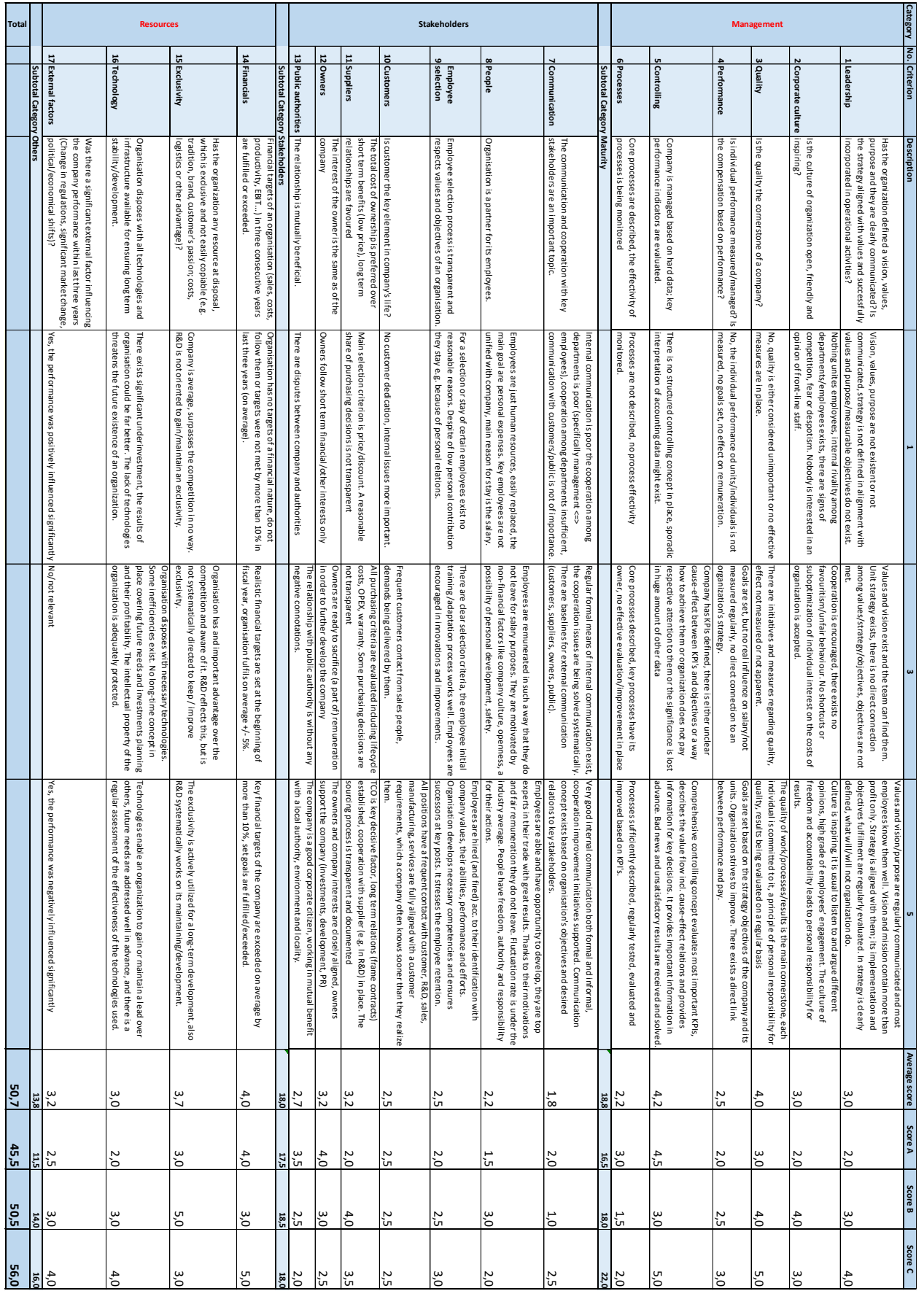

Source: own elaboration 
The model consists of 17 criteria grouped in 3 categories, a leading question for each with descriptions of rankings 1/3/5. Figure 2 shows illustrative scoring for three virtual respondents, their average score and score for each category. The interpretation is based on the descriptions of each criterion, where level 3 means no better than the average result with a room for improvement. Results scoring better than 3 need no particular attention, just in case the deviations are high for a criterion it needs explanation. In case the result is below 3 , attention is needed, particularly for results under 2 . Result 1-2 is unsatisfactory with a potential negative impact on an organisation's performance over the long term.

\subsection{Graphical output}

Figure 2 shows the graphical output of a CAT model. It allows the assessor to evaluate each respondent (could be disclosed for publication for ensuring anonymousness, if needed). Average score and main deviations from it are a concern for the evaluation.

Figure 2 | An example of CAT Model results in a web chart

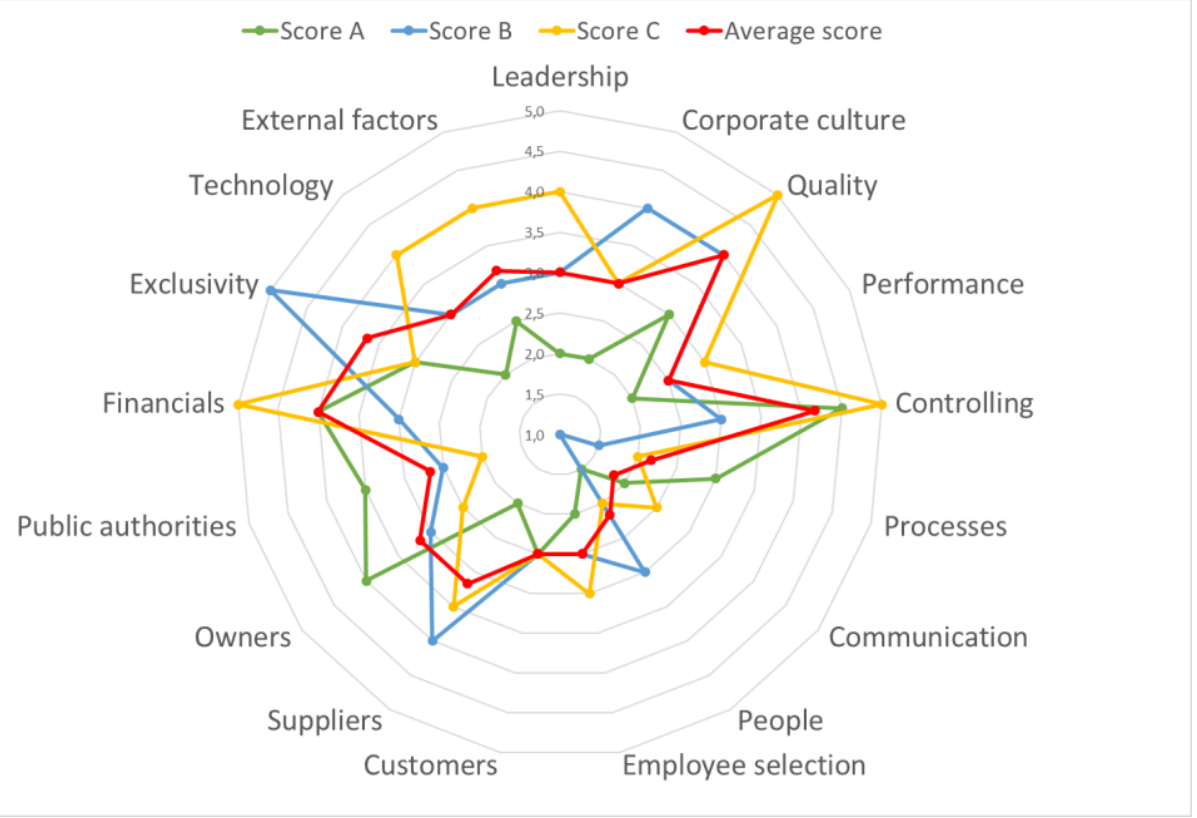

Source: own elaboration

\subsection{Structured interpretation of results}

This part of the model allows the assessor to provide the tested organisation with unified, structured comments and identification of strong/weak sides. It is based on the overall model score and also scores reached in each category/criterion. In certain case, it can also provide proposals for improvement. A comparison with older results and possible development over time can also be evaluated here. 


\section{Model verification}

Every model created has to undertake a verification and testing phase. The verification of the model took over a year and was based on 12 companies. Long et al., 2020 states that appropriate is 8-16 test subjects, what is compliant with our testing procedure. Testing based on the questionnaire can extend the number of subjects but would reduce the quality of feedback as the personal contact would be missing. Therefore, the CAT model has been tested on 12 different Czech and international companies, from micro-enterprises to branches of multinationals (see Appendix 1 for further details).

The selection of organisations was not random, as no interpretation of results was foreseen. The selection criteria were to involve different companies regarding its size, country of origin and businesses. The graphical overview is presented in Figures $3 a$ \& $3 b$ and 4.

Figure 3a \& 3b | Participating Organisations - division acc. to the country of origin and industry sectors

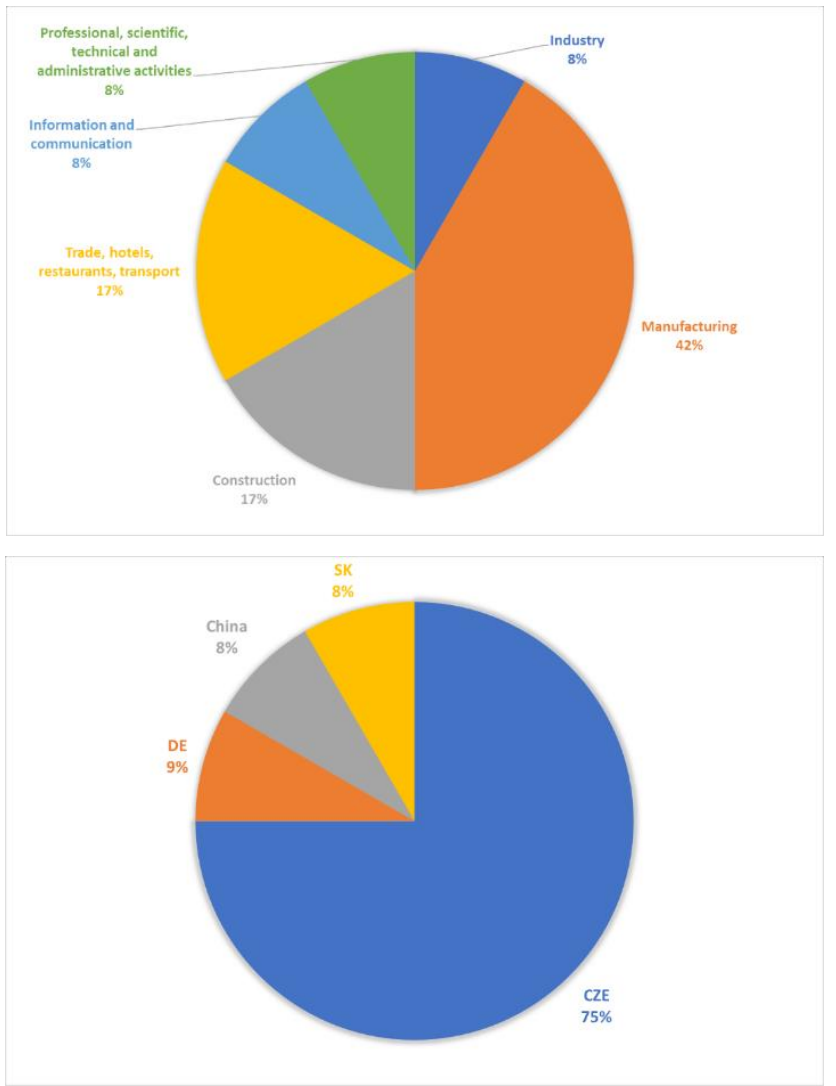

Source: own elaboration 


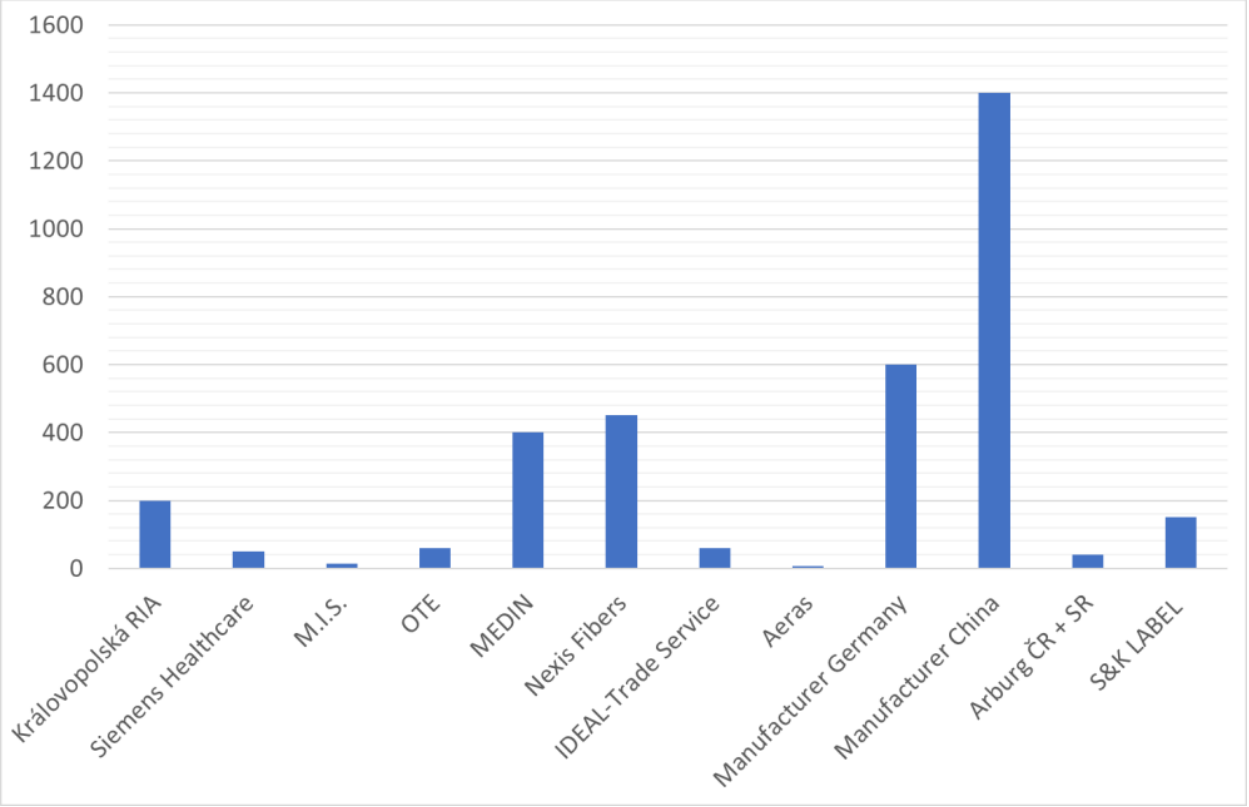

Source: own elaboration

During the research, a number of three participants from an organisation proved to be optimal. Less than three is biased by the "helicopter view" of top management. More than three tends to be more resources demanding not contributing to the better results significantly (see chapter 6 for more detailed view). To get unbiased results, it has proven better to get an open answer from a participant and only then to scale it. Otherwise, they tend to evaluate themselves, often to look more favourable than in reality. Several other improvements during the verification phase were developed (graphical output, a subscore for each category, redesign of categories and criteria).

The feedback received from participating managers was very positive, and four of ten tested companies used assessment results, even though obtained from the beta version, for their own improvement purposes. So even in the testing phase, the CAT Model has had some positive effects on evaluated organisations (which is actually the purpose why the CAT model was created). Some others expressed interest in using its finalised version to track their development. Especially micro-companies were not interested very much as their management systems still need to evolve. Also, the feedback from multinational concern was positive, but no further interest was expressed. This can be because of so many own controlling, reporting, audit and management tools exist that no new tool is particularly welcomed. Based on that, the testing of the model was finished, and the model validation phase began.

The last phase of the research, after a literature review, CSF identification, model creation and testing was the final model validation on two companies. It consisted of backward interpretation, it means, the results have been discussed with the management of the companies in detail and compared to their own view of the organisation. In both cases, the 
results were accurate, corresponding with the management view. The first assessment was presented on management meeting with employees with very positive feedback - the strong/weak points were acknowledged, and further improvement process started. Disclosure of further details was not allowed by management. In the other case, it was part of change management, provided material for strategy meetings with owners and management and formed a basis for the transformation process. The process had shown positive financial effect after three months from deploying. It consisted of personal changes, customer profitability analyses, calculation and sales processes changes, improvement in logistics and manufacturing. The usage and the model results were recommended for practical usage. Thought further modification is possible and probable (e.g. EFQM Model is being updated every two years), we consider the model as usable in bot academic research and business praxis.

\section{Usability, constraints, further research}

Based on the results of the verification process, described in chapter 5 in detail, the CAT Model finished its development phase and is ready for its practical use. In spite of the fact that future development and reengineering might take place, it is a robust and reliable tool at this stage to evaluate an organisation. Its expected use is in mid-sized organisations, which aim to develop themselves or want to identify a possible root cause of their problems (e.g. productivity, fluctuation, quality,...). Organisations can perform an assessment over a certain time period to evaluate possible improvement in critical areas.

There are several rules/constraints which have to be observed during the execution of an assessment based on the CAT model. Firstly, the model is designed for three respondents. The reason is that interviews on top management level have proven that they sometimes possess a "helicopter view" leading to biased results (usually, but not always, overestimating certain categories like communication and culture). More respondents make the assessment more resource demanding, not contributing to higher reliability significantly. The reason is that the balance among the top management, executive management and employees shall be balanced. If we increase the number of participants, we shall either increase in all three categories described below, what might not be possible or to increase the weight of responses of category, which is not represented by so many respondents. This seems not an appropriate way of conducting the assessment. If broader sample opinion is wanted, it is, of course, possible to include questions from the CAT model into, e.g. employee satisfaction survey.

The correct assessment shall therefore include a top manager or owner, in case he is managing actively. The second respondent shall be another high-level manager, who has the best overview of processes and daily business-preferably executive director, financial director or similar. The third respondent shall be an opinion maker, a person who is close to the front-line employees but has a good overview of the organisation. This can be HR manager, head of trade unions, compliance officer, ombudsman or alike. It is important that such a person has respect from employees, knows their opinions, but on the same hand has certain managerial ability to be able to cope with questions on the desired level. Each participant is interviewed separately.

Secondly, the CAT model is not suitable for micro organisations with fewer than 20-25 people. The processes are usually not set, most of the operations and decisions are spontaneous, 
and communication is informal. The results of an evaluation are usually low /average, even for well-performing companies. The obtained responses and subsequently, evaluations are sometimes inadequately strict. On the other hand, it shows the management/owner of the areas they have to develop if they aim for further growth.

Thirdly, also for branches of multinationals, there are some constraints. The strategies, values, processes etc. are set from $\mathrm{HQ}$, and people from subsidiaries may not be fully aware of them. Therefore, the results might be influenced. For corporations can be an EFQM model recommended as it has strong descriptive power (at the cost immense effort, not comparable with CAT).

Lastly, it is important that the interviewer has a good knowledge of the model to be able to scale the results correctly. It is instructive as much as it can be, but still, the answers, in reality, can vary from description states, and it is desirable to have standardised and comparable output.

For further research were two main areas identified. Firstly, to conduct a quantitative in-field research to obtain a broader database of results, enabling to scale the results better and to create a benchmark over certain parameters (size of a company/industry/life cycle of the company), thus improving also the feedback to the companies. Secondly, further qualitative research leading to incorporate non-profit organisations in the model. It has been built nonprescriptive (generally used for any kind of organisations), so no obstacles shall exist to use it for non-profits too. In the development phase was this segment not present, so no relevant results can be given.

\section{Conclusion}

There are many performance models in place. Existing performance management tools and models are in the majority not designed to assess an organisation, or even to provide comparable results, with the exceptions of EFQM and Baldrige's Award Criteria. Both are too complicated and resources /knowledge demanding to be used in smaller organisations; after a literature review, no existing model able to assess a management quality of an organisation with measurable results is known to the authors.

A contemporary tool has been created to evaluate the level of maturity in an organisation. The CAT model offers a strong, yet lean and easy-to-use tool for both the academic sphere and practitioners. The model and assessment methodology aims at small and medium enterprises as they generally do not have enough resources and expertise to conduct a largescale assessment on their own. The results are scalable, comparable over time and enable benchmarking. Field testing was conducted during the model development phase on 12 international companies leading to gradual improvements of the model. Its results have been acknowledged not only by managers but also by middle management and employees. It offers not only a descriptive and benchmarking tool, but the intention is to give owners/managers a tool to identify strong/weak sides of their organisation to further develop it. They are able to compare their own results over time so that they can evaluate the success of change efforts. 


\section{Appendix 1: A list of companies interviewed}

Královopolská RIA, a. s.

Královopolská RIA is a Czech construction company founded in 1996. It has had approx. 200 employees in a time of evaluation. Since 2017 it has filed for bankruptcy.

Siemens Healthcare, Czech subsidiary of world leader in medical equipment in fields of screening, diagnostics and postprocessing, employing 60 people.

MIS s.r.o. provides IT solutions for media and broadcasting companies. It was founded in 1995. MIS has under 20 employees.

OTE, a. s. acts as an operator on Czech energy market. It is a public company with 60 employees.

MEDIN, a. s., is a private company producing steel implants for traumatology, surgery, orthopaedics and stomatology. MEDIN has over 400 employees.

Nexis Fibers a. s. is Slovak company producing artificial fibres. It employs over 450 people.

IDEAL-Trade Service, spol. s r.o. delivers solutions for painting workshops, chemicals for surface treatments and compressors. Has been founded in 1993 and has over 60 employees.

Aeras, s.r.o. is a construction company delivering dedusting technologies for heavy industry. It has under 10 employees and is one of micro-companies in a survey.

\section{Manufacturing plant Germany}

\section{Manufacturing plant China}

This companies do not want to be disclosed, only number of employees (600 / 1400 respectively) can be given. Both are a part of an international corporation.

\section{Arburg Czech/Slovak subsidiary}

Company Arburg is leading producer of plastics injection machines. Local subsidiary has 40 employees.

S\&K LABEL spol. s r.o. operates since 1991 as a central European leader in self-adhesive labels. It has over 160 employees. 
Appendix 2: A list of models, tools and techniques analysed

\begin{tabular}{|c|c|c|c|c|}
\hline Financials & Management tools & $\begin{array}{ll}\text { Performance } & \text { management } \\
\text { systems (PMS) } & \end{array}$ & $\begin{array}{l}\text { Marketing and } \\
\text { strategy tools }\end{array}$ & $\begin{array}{l}\text { Tools and techniques - } \\
\text { others }\end{array}$ \\
\hline $\begin{array}{l}\text { Altman Z- } \\
\text { Score }\end{array}$ & AMBITE & $\begin{array}{l}\text { Baldrige performance } \\
\text { excellence model }\end{array}$ & 5Forces model & Brown's model \\
\hline $\begin{array}{l}\text { Argenti } \\
\text { score }\end{array}$ & CorSet framework & BSC (Balanced Scorecard) & BCG & EFE matrix \\
\hline $\begin{array}{l}\text { DuPont } \\
\text { Pyramid }\end{array}$ & $\begin{array}{l}\text { Four phases of } \\
\text { change }\end{array}$ & Capability Maturity Model & McKinsey 7S & IFE matrix \\
\hline IN model & $\begin{array}{l}\text { Harry Pollak's } \\
\text { viability model }\end{array}$ & $\begin{array}{l}\text { Dixon's } \\
\text { questionnaire }\end{array}$ & MIT 90's & Leavitt's diamond \\
\hline \multirow[t]{15}{*}{$\begin{array}{l}\text { Zero-Based } \\
\text { Budgeting }\end{array}$} & $\begin{array}{l}\text { Kotter's Eight Step } \\
\text { Change Model }\end{array}$ & $\begin{array}{l}\text { Dynamic } \quad \text { Performance } \\
\text { Management (DPM) }\end{array}$ & PESTLE & VRIO \\
\hline & $\begin{array}{l}\text { Lewin's three stage } \\
\text { model of change }\end{array}$ & EFQM & SPACE & Advanced Analytics \\
\hline & Model CAF & ENAPS & SWOT & Agile Management \\
\hline & $\begin{array}{l}\text { A diagnose matrix } \\
\text { for assessing } \\
\text { organisational risk } \\
\text { maturity }\end{array}$ & $\begin{array}{l}\text { Keegan's performance } \\
\text { measurement matrix }\end{array}$ & Benchmarking & $\begin{array}{ll}\text { Business } & \text { Process } \\
\text { Reengineering } & \end{array}$ \\
\hline & Good to Great & $\begin{array}{l}\text { Medori and Steeple } \\
\text { Framework }\end{array}$ & $\begin{array}{l}\text { Blue Ocean } \\
\text { Strategy }\end{array}$ & Complexity Reduction \\
\hline & $\begin{array}{l}\text { Sink and Tuttle } \\
\text { model }\end{array}$ & Performance Prism & $\begin{array}{l}\text { Customer } \\
\text { Relationship } \\
\text { Management }\end{array}$ & Core Competencies \\
\hline & $\begin{array}{l}\text { Six Sigma Business } \\
\text { Scorecard }\end{array}$ & TOPP System & $\begin{array}{l}\text { Customer } \\
\text { Satisfaction } \\
\text { Systems }\end{array}$ & $\begin{array}{l}\text { Customer } \\
\text { Analysis }\end{array}$ \\
\hline & $\begin{array}{l}\text { Principy pokročilých } \\
\text { systémů } \\
\text { managementu } \\
\text { kvality }\end{array}$ & $\begin{array}{l}\text { A performance measurement } \\
\text { system for SMEs taking part in } \\
\text { Quality Award Programmes }\end{array}$ & $\begin{array}{l}\text { Customer } \\
\text { Segmentation }\end{array}$ & Digital Transformation \\
\hline & $\begin{array}{l}\text { Six dimensions } \\
\text { performance } \\
\text { measures }\end{array}$ & $\begin{array}{l}\text { High Performance } \\
\text { organisations framework }\end{array}$ & $\begin{array}{l}\text { Change } \\
\text { Management } \\
\text { Programs }\end{array}$ & $\begin{array}{l}\text { Employee Engagement } \\
\text { Systems }\end{array}$ \\
\hline & $\begin{array}{l}\text { Phases of } \\
\text { performance } \\
\text { measurement } \\
\text { implementation }\end{array}$ & ISAT & $\begin{array}{l}\text { Mission and Vision } \\
\text { Statements }\end{array}$ & Internet of Things \\
\hline & & $\begin{array}{l}\text { Performance } \\
\text { system model }\end{array}$ & $\begin{array}{l}\text { Price Optimisation } \\
\text { Models }\end{array}$ & $\begin{array}{l}\text { Mergers } \\
\text { Acquisitions }\end{array}$ \\
\hline & & $\begin{array}{l}\text { THE } \quad \text { ENTERPRISE } \\
\text { MATURITY MATRIX }\end{array}$ & $\begin{array}{l}\text { Scenario } \\
\text { Contingency } \\
\text { Planning }\end{array}$ & $\begin{array}{l}\text { Organisational } \\
\text { Management }\end{array}$ \\
\hline & & Bititci's Reference model & Strategic Alliances & PDCA Deming cycle \\
\hline & & $\begin{array}{l}\text { Performance } \\
\text { (SMART) }\end{array}$ & Strategic Planning & $\begin{array}{l}\text { Stankosky's Four Pillar } \\
\text { Knowledge } \\
\text { Management Model }\end{array}$ \\
\hline & & $\begin{array}{l}\text { The Results and Determinants } \\
\text { Framework }\end{array}$ & $\begin{array}{l}\text { Supply Chain } \\
\text { Management Quality } \\
\text { Total } \\
\text { Management }\end{array}$ & \\
\hline
\end{tabular}

Source: own elaboration 


\section{References}

Afonina, A. (2015). Strategic Management Tools and Techniques and Organizational Performance: Findings from the Czech Republic. Journal of Competitiveness, 7(3), 19-36. https://doi.org/ 10.7441/joc.2015.03.02

Ariyadi, D., \& Dirgahayu, T. (2015). Assessment to COBIT 4.1 maturity model based on process attributes and control objectives. 2015 International Conference on Science in Information Technology (ICSITech), 343-347.

Aschenbrennerova, H. (2010). Měřením a řízením výkonnosti ke zvyšování konkurenceschopnosti malých a středních průmyslových podniků v období globální finanční krize. Journal Úspěch, 10(1), 12-14.

ASIS (2013). Maturity Model for the Phased Implementation of a Quality Assurance Management System for Private Security Service Providers. ASIS International.

Belt, P., Oiva-Kess, A., Harkonen, J., Mottonen, M., \& Kess, P. (2009). Organisational maturity and functional performance. International Journal of Management and enterprise development, 6(2), 147-164.

Bencsik, A. (2017). Knowledge management initiatives and strategies in small and medium enterprises. IGI Global.

Bititci, U., \& Begemann, C. (2000). Dynamics of performance measurement systems. International Journal of Operations \& Production Management, 20(6), 692-704.

Bititci, U. S. (2016). Managing business performance: The science and the art. John Wiley \& Sons.

Blanchard, B. S., \& Fabrycky, W. J. (2016). Systems Engineering and Analysis. Prentice-Hall.

Clark, D. N. (1997). Strategic management tool usage: a comparative study. Strategic Change, 6, 417427.

CMMI Product Team. (2010). CMMI for Development, Version 1.3 (CMU/SEI-2010-TR-033). Software Engineering Institute, Carnegie Mellon University website. http://resources.sei.cmu.edu/library/asset-view.cfm?AssetID=9661

Collins, J. C. (2001). Good to Great: Why Some Companies Make the Leap... and Others Don't. Harper Collins.

Danso, P., Kong, Y., Owusu-a. M., \& Afriyie, S. (2019). Empirical Analysis of the Relationship between Leadership and Organisational Performance. International Journal of Multidisciplinary Research Review, 7, 956.

David, F. R. (2011). Strategic Management: Concepts and Cases. Prentice Hall.

de Waal, A. (2010). The Characteristics of a High Performance Organisation. SSRN Electronic Journal https://doi.org/10.2139/ssrn.931873

Dijkman, R., Lammers, S. V. \& Jong, A. D. (2015). Properties that influence business process management maturity and its effect on organizational performance. Information Systems Frontiers, 18(4), 717-734. https://doi.org/10.1007/s10796-015-9554-5

Freeman, E. (1984). Strategic Management: A Stakeholder Approach. Pitman.

Frost, F. A. (2003). The use of strategic tools by small and medium-sized enterprises: an Australasian study. Strategic Change, 12(1), 49-62. https://doi.org/10.1002/jsc.607 
Garengo, P. (2009) A performance measurement system for SMEs taking part in Quality Award Programmes. Total Quality Management, 20, 91-105. https://doi.org/10.1080/14783360802614307

Garengo, P., Biazzo, S., \& Bititci, U. S., (2005). Performance measurement systems in SMEs: A review for a research agenda. International Journal of Management Reviews, 7(1), 25-47.

Globerson, S. (1985). Issue in developing a performance criteria system for an organisation. International Journal of Production Research, 23(4), 639-646.

Hálek, V. (2016). Non-financial indicators in the valuation process. Sciemcee Publishing.

Ittner, C. D., \& Larcker, D. F. (2003). Coming Up Short on Nonfinancial Performance Measurement. Harvard Business Review. https://hbr.org/2003/11/coming-up-short-on-nonfinancialperformance-measurement?autocomplete=true.

Jokela, T., Siponen, M., Hirasawa, N., \& Earthy, J. (2006). A survey of usability capability maturity models: Implications for practice and research. Behaviour \& IT, 25, 263-282. https://doi.org/10.1080/01449290500168079

Kaplan, R. S., \& Norton, D. P. (1996). Linking the Balanced Scorecard to Strategy. California Management Review, 39(1), 53-79.

Kaplan, R. S., \& Norton, D. P. (2000) Balanced scorecard: strategický systém měření výkonnosti podniku. Management Press.

Kennerley, M., \& Neely, A. (2003). Measuring performance in a changing business environment. International Journal of Operations \& Production Management, 23(2), 213-229. https://doi.org/ 10.1108/01443570310458465

Kim, W. C, \& Mauborgne, R. (2005). Strategie modrého oceánu: umění vytvoriit si svrchovaný tržní prostor a vyřadit tak konkurenty ze hry. Management Press.

Klarner, P. \& Raisch, S. (2013). Move to the beat - rhythms of change and firm performance. The Academy of Management Journal, 56(1), 160-179.

Knorová, K. (2015). Měření výkonnosti a jeho propojení se systémem odměňování. Český finanční a účetní časopis, 10(4), 116-132.

Kotter, J. P. (1995). Leading change: why transformation efforts fail. Harvard Business Review, 59-67.

Kotter, P. \& Heskett, L. (1992). Corporate Culture and Performance. Macmillan.

Kovandová, J. (2015). Modely měření a řízení výkonnosti v podnicích. Fakulta ekonomická ZČU v Plzni.

Kwak, Y.H., \& Ibbs, C.W. (2002). Conference Proceedings: Project Management Process Maturity (Pm)2 Model.

Long, T. B., Blok, V., Dorrestijn, S., \& Macnaghten, P. (2020) The design and testing of a tool for developing responsible innovation in start-up enterprises, Journal of Responsible Innovation, 7(1), 45-75. https://doi.org/10.1080/23299460.2019.1608785

Lynch, R. L., \& Cross, K. F. (1990). Measure Up! Yardsticks for Continuous Improvement. Basil Blackwell.

Maisel, L. S. (2001). Performance measurement practices survey results. American Institute of Certified Public Accountants.

Malina, M. A., Nørreklit, H. S., \& Selto, F. H. (2011). Lessons learned: advantages and disadvantages of mixed method research. Qualitative Research in Accounting \& Management, 8(1), 59-71. https://doi.org/10.1108/11766091111124702 
Model excelence EFQM 2013. (2013). EFQM Foundation.

Národní cena kvality ČR (2013). Model START PLUS. Národní informační středisko podpory kvality.

Neely, A. D., Adams, C., \& Kennerley, M. (2002). The performance prism: The scorecard for measuring and managing business success. Prentice Hall Financial Times.

Nenadál, J. (2016). Systémy managementu kvality: co, proč a jak měřit? Management Press.

Ogbonna, E., \& Harris, L. (2000). Leadership style, organizational culture and performance: Empirical evidence from UK companies. International Journal of Human Resources Management, 11(4), 766-788.

Oger, B., \& Platt, D.E. (2002). Value Measurement and Value Creation Models in Europe and the US: A Comparison of the EFQM Excellence Model and the Baldrige Award Criteria. COMPTABILITE CONTROLE - AUDIT / special edition May 2002 (99 - 116).

Otley, D. (1999). Performance management: a framework for management control systems research. Management Accounting Research, 10(4), 363-382.

Peters, T., \& Waterman, R. (1982) In Search of Excellence. New York: Random House.

Peters, T. J. (2014). In Search of Excellence at (Almost) 25 ... and Standing Tall. https://tompeters.com/2006/11/in-search-of-excellence-at-almost-25-and-standing-tall/

Piszczur, R. (2013). Vliv strategického řízení na výkonnostní kritéria organizace. The International Scientific Conference INPROFORUM 2013, 227-232.

Pollak, H. (2003). Jak obnovit životaschopnost upadajících podniků. C. H. Beck.

Porter, M. E. (1980). Competitive Strategy - Techniques for Analyzing Industries and Competitors. The Free Press.

Rigby, D., \& Bilodeau, B. (2017). Management Tools \& Trends. Bain \& Company, Inc. https://www.bain.com/contentassets/caa40128a49c4f34800a76eae15828e3/bain_briefmanagement_tools_and_trends.pdf

Rothaermel, F. T. (2014). Strategic management: Concepts and cases. Mcgraw-Hill Inc.

Rusev, S. J., \& Salonitis, K. (2016) Operational Excellence Assessment Framework for Manufacturing Companies. Procedia CIRP. 55, 5th CIRP Global Web Conference - Research and Innovation for Future Production (CIRPe 2016), 272-277.

Simons, R. (2000). Performance measurement and control systems for implementing strategy. Prentice Hall.

Štamfestová, P. (2013). Hodnocení výkonnosti podniků. Masarykova univerzita.

Suchánek, P. (2013). Vliv kvality na výkonnost a konkurenceschopnost podniku. Masarykova univerzita.

Tenhunen, J., Rantanen, H., \& Ukko, J. (2001). SME-oriented Implementation of a Performance Measurement System. Department of Industrial Engineering and Management.

van Aken, E. M., Letens, G., Coleman, G. D., Farris, J., \& Goubergen, D. V. (2015). Assessing maturity and effectiveness of enterprise performance measurement systems. International Journal of Productivity and Performance Management, 54(5/6), 400-418. https://doi.org/10.1108/17410400510604557

Vochozka, M. (2011). Metody komplexního hodnocení podniku. Grada. 
Welch, M., \& Jackson, P. R. (2007). Rethinking internal communication: a stakeholder approach. Corporate Communications. An International Journal, 12(2), 177-198. https://doi.org/10.1108/13563280710744847

Zairi, M. (2010). Becoming World Class Through a Culture of Measurement. European Centre for Best Practice Management.

The research paper passed the review process. | Received: March 3, 2020; Revised: June 14, 2020; Accepted: June 23, 2020; Published: December 21, 2020 